\title{
Design and implementation automation system for hydroponic vegetable cultivation
}

\author{
Zuriati $^{1^{*}}$, M Apriyani ${ }^{2}$ and AR Supriyatna ${ }^{1}$ \\ ${ }^{1}$ Informatics Management, Politeknik Negeri Lampung, Bandar Lampung, Indonesia \\ ${ }^{2}$ Agribusiness, Politeknik Negeri Lampung, Bandar Lampung, Indonesia
}

\begin{abstract}
*Corresponding author: zuriati_mi@polinela.ac.id
Abstract. This research is about the design of an automation system by using microcontroller technology. The automation system defined in this research is the automation in the irrigation and fertilization process that has been designed by the needs for hydroponic vegetable cultivation, in an attempt to help hydroponic farmers and the community in controlling and caring for vegetables automatically. The research stages are initiated from analyzing the needs of system development, continued by designing hardware and software, and implementing automation systems for the last stage. The developed automation system consists of 1 module, 1 sensor, Arduino Uno, and 2 relays and pumps. The RTC module is utilized to adjust the fertilizer scheduling time, while the utilization of a water level sensor is aimed to detect the water level in hydroponic vegetable installations. Arduino Uno is utilized as a microcontroller to process all data generated from the automation system. The data sent by the two sensors then will be processed to the objective of turning on the relay. In this system, 2 relays are used. The first relay is a relay as a switch to turn on the water filling pump and the second relay is a relay for the fertilization pump. Furthermore, the automation system is equipped with 2 pumps aiming for filling water and fertilizing hydroponic vegetables. The working system is repeating each instruction regularly according to the program instructions that are made. This research has succeeded in making a prototype of an automation system for hydroponic vegetables, it is hoped that this prototype can be used by farmers and the general public in hydroponic vegetable cultivation to achieve more satisfying results.
\end{abstract}

\section{Introduction}

It is currently acknowledged that the issue of food security has received serious attention and studies from various parties, particularly from the government of Indonesian. The connection between the availability of food, the extent of agricultural land, and an increase in population is unavoidably subsisted. The data of the Central Bureau of Statistics reveal that in the results of the 2015 InterCensus Population Survey (SUPAS), the number of Indonesia's population is predicted to grow significantly. In 2015 the number was 255.6 million, however by the year 2030, it is estimated that the number will increase to 294.1 million. Meanwhile, based on BPS data (2018) there was a decrease in the area of agricultural land [1]. In the year 2018, there were 7.1 million hectares, while it was previously 7.75 million hectares in 2017 . With this condition of the reduction of the agricultural land, there is nothing to expect besides the decrease of the food yields. Therefore, to overcome the limited land problem and fulfill the need for food on the daily basis, one-way particular action should be executed. The particular way is by applying the hydroponic farming method or urban farming. 
According to Eridani (2017), hydroponics is a way of farming where the planting medium used is water instead of soil [2]. The hydroponic method has several advantages. The application of the hydroponic method will gain more production, use less land and nutrients, and control pests and diseases easily. However, farming in this hydroponic way requires a controlled environment, maintenance, and care compared to farming with soil media. To get maximum yields, it is advisable to control nutrients, environmental temperature, water conditions, $\mathrm{pH}$, and humidity. The water used must meet certain requirements, for example, nutrient content, $\mathrm{pH}$, turbidity level, temperature, and volume. This is because the process of vegetable development is highly dependent on the conditions of the water contained in the hydroponic media. Giving proper hydroponic nutrition will provide optimal results for the growth of the vegetable. Besides, vegetable plants cannot be separated from the growing environment, particularly the growing media factor which directly affects vegetable yields [3].

Farmers and hydroponic practitioners must lay serious attention to the conditions of water and fertilizers that must be provided on hydroponic media, for the best result of the growth of hydroponic vegetables. Helmy (2016) explains that the volume and temperature of the water are very volatile, so farmers and hydroponic practitioners have difficulty monitoring them [4]. To gain the best result of the growth of the plants, farmers must monitor the volume of water continuously and repeatedly. This is considered hard and time-consuming. Therefore, based on this situation, farmers and hydroponic practitioners need a system that enables them to control the volume of water and take the necessary actions in caring for hydroponic vegetables. The system must enable them to acknowledge when hydroponic vegetables require an additional volume of water and fertilizer, and add water and also provide fertilizer automatically.

Generally, the hydroponic farming carried out by the community still uses a simple system. This system is relatively more expensive in terms of costs. The high cost occurs because they have to control the $\mathrm{pH}$, temperature, nutrient density, and water quantity periodically. As the result, farmers need more time and money to care for hydroponic vegetables, especially in controlling the quantity of water required by hydroponic vegetables. This problem, for sure, needs a solution. There should be a method in such a way that can monitor the condition of hydroponic vegetables automatically. Based on these backgrounds, problems in this study can be formulated as to how to design a system that can automate irrigation and fertilization on hydroponic vegetables.

The main objective of this article is to design an automation system for watering and fertilizing hydroponic vegetables. The automation system defined is automation in terms of controlling the quantity of the water and automation in applying fertilizers. This system is required to fulfill the needs of vegetables on a household scale to a production scale so that it can increase farmers' income. Another benefit that will be gained is a reduction in human labor because the control process of watering and fertilizing is carried out utilizing automatic equipment, so that the costs incurred for the maintenance wages will be reduced, as a result, the income of the farmers and the community will increase.

The research on the application of information technology in agriculture has been carried out in an attempt to provide solutions to the encountered problems, specifically for the application of information technology in the form of an automation system in hydroponic vegetable cultivation. Several previous studies have been carried out, including the research of Wahyudin et al [5], that have made a system in monitoring and automation of planting media moisture for web-based hydroponic vegetables. The system is developed of two parts, they are the remote terminal unit (RTU) and the control terminal unit (CTU). RTU consists of an ATSAM3X8E microcontroller and a microprocessor that functions to acquire moisture data for planting media and send data to the database via the internet network. For automatic watering of vegetables, Yudhana and Putra (2016) constructed watering automation based on a moisture sensor [6]. Another research was conducted by Pratama et al (2018) by developing an automatic water control system for hydroponic vegetables [7]. This system is built using Arduino Mega 2560 and an RTC timer to regulate the process of filling water into the tank. Meanwhile, Ibadarrohman et al (2018) created a control and monitoring system for android-based 
hydroponic vegetables [8], for Julyana (2017) kale vegetables by using a microcontroller for automatic nutritional control [9].

\section{Methods}

The stages of the research for the development of this automation system prototype are:

1. Analysis Stage

The analysis stage is the stage of analyzing the needs for the development of an automation system, both functional and non-functional requirements. Analysis of functional requirements is an analysis of the functions that can be performed by an automation system. Meanwhile, nonfunctional requirements analysis is an analysis that is not related to system functions, such as the selection of tools and materials, hardware, and software used.

2. Design Stage. This stage consists of two phases:

i. The hardware design, which is in the form of sensor system design, microcontroller system, relay system, pump system, spraying system, and fertilization system.

ii. The software design, which is in the form of program logic design.

3. Implementation Stage.

At the implementation stage, several sub-stages were carried out, they are: determining hardware and software, making automation system hardware prototypes, and making software programs.

\section{Results and Discussions}

\subsection{The Analysis Stage}

The result of this analysis phase is defining the functional requirements of the automation system and the non-functional requirements. Analysis of functional requirements is defined as an analysis of the functions that can be performed by an automation system. For functional requirements, the automation system can perform watering and fertilizing functions. The watering process is scheduled at $7.00 \mathrm{am}$ and $3.00 \mathrm{pm}$. Besides, the automation system can also carry out the fertilization process according to a predetermined schedule 1x in 1 week. Meanwhile, non-functional requirements analysis is an analysis that is not related to system functions, such as the selection of tools and materials used.

The next step is executing the block diagram design of the automation system. In Figure 1, the results of the block diagram design for the hydroponic vegetable cultivation automation system are presented.

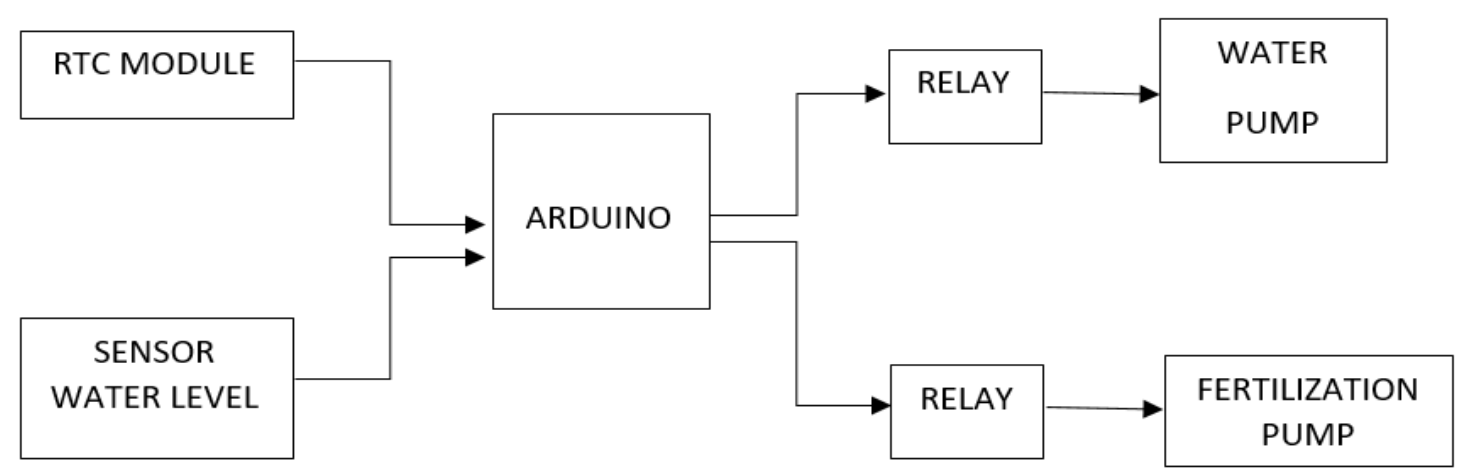

Figure 1. Block Diagram

Based on the block diagram in Figure 1, it is explained that the system works using 1 module, namely a real-time clock (RTC) and a water level sensor. The RTC module is used as a scheduling time for fertilizing hydroponic vegetables. So at a certain time, the system will regularly fertilize the vegetables. The water level sensor is used to detect the water level based on the resulting voltage 
resistance which is then converted into data bits to determine the water level in hydroponic vegetables. If the sensor detects a low water level, the system will turn on the water filling pump to fill the water in the pipe and if the water level has reached the maximum limit, the filling pump will automatically stop. Apart from 2 sensors, another device is Arduino Uno which is used as a microcontroller to process all existing data, both data from input and data for output. The data sent by the two sensors will be processed to turn on the relay. Two relays are used as switches to turn on the water filling pump and the fertilization pump. This system will always loop regularly according to the designed program instructions.

\subsection{The Design Stage}

The automation system design stage consists of designing hardware and designing software. The hardware design consists of designing a voltage source circuit, designing an RTC module circuit, designing a level sensor circuit, and designing a water level sensor. The following is the explanation of the results of the hardware design experiments that have been executed.

\subsubsection{The Voltage Source Circuit Design}

The voltage source circuit is utilized to change the AC $220 \mathrm{~V}$ to $12 \mathrm{~V} \mathrm{DC}$ voltage and distribute the voltage source to all electronic components in the circuit, as the result, the circuit in the automation system can work and function properly. In Figure 2, the voltage source circuit of the automation system is presented.

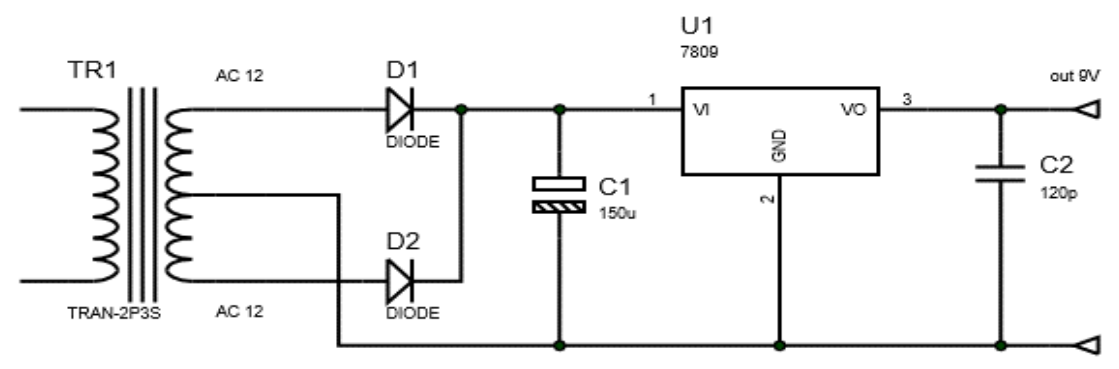

Figure 2. Voltage Source Circuit Design

\subsubsection{The RTC Module Circuit Design}

Figure 3 is presented the series of RTC modules. The RTC circuit is connected to the Arduino to detect real-time which is then used as a schedule for hydroponic vegetable fertilization.

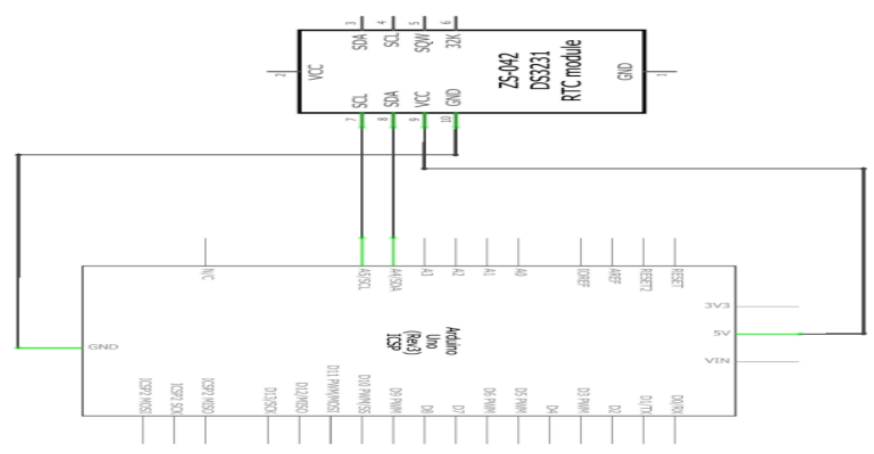

Figure 3. RTC Module Circuit Design

\subsubsection{The Water Level Sensor Circuit Design}

In Figure 4, the design drawing of a water level sensor is presented. 


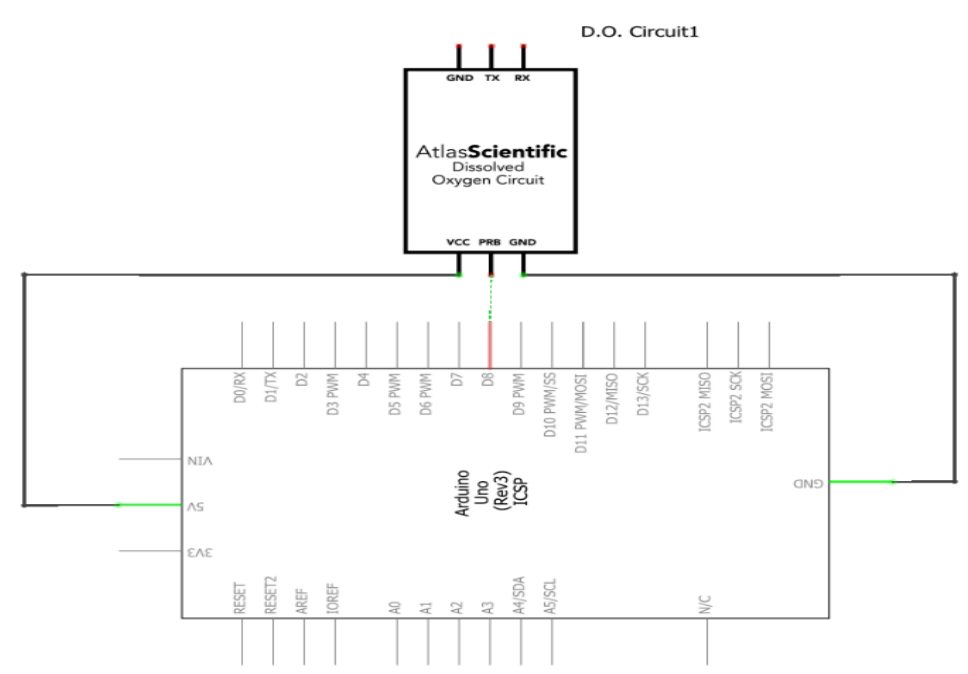

Figure 4. RTC Sensor Circuit Design

The water level sensor circuit is connected to Arduino to detect the water level in the hydroponic vegetable pipe which is then used as an indicator to turn on the water filling pump and fertilization pump.

\subsubsection{The Relay Circuit Design}

In Figure 5, a system relay circuit is presented.

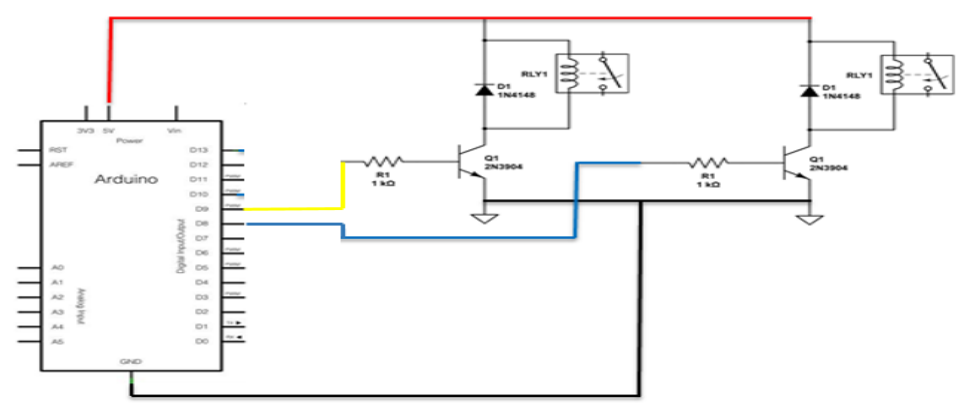

Figure 5. Relay Circuit Design

The relay circuit is connected to one of the cables on the water filling pump and hydroponic vegetable fertilization pump which is used to temporarily cut the current or as a switch. The water filling pump and fertilizer pump will work when the relay position is normally open.

\subsubsection{The Implementation Stage}

At the implementation stage, the entire series of hardware and software that has been produced previously are combined in the form of an overall automation system. The hardware design in the form of a whole series of automation systems is a combination of RTC module, water level sensors, Arduino, and relay circuits that are integrated into one unit for the management of hydroponic vegetables in performing automatic scheduled watering and fertilization. Figure 6 is presented a series of the whole system. 


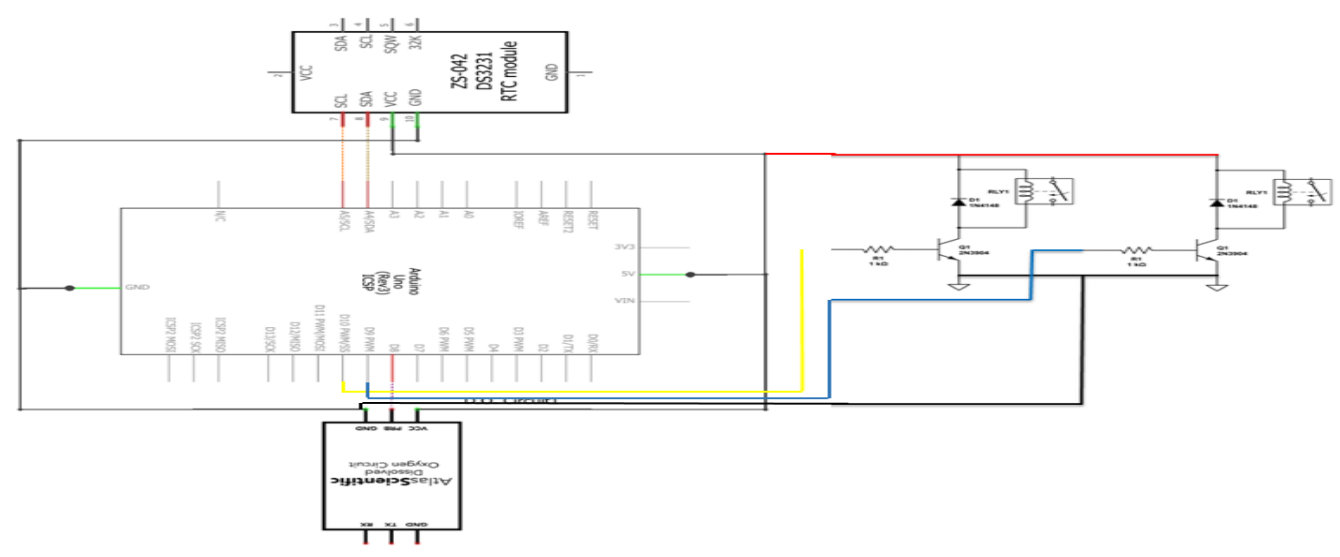

Figure 6. A Series of The Whole System

The program logic design is described in the form of a flowchart to simplify the illustration of the logic of the automation system program. In Figure 7, the automation system flowchart is presented.

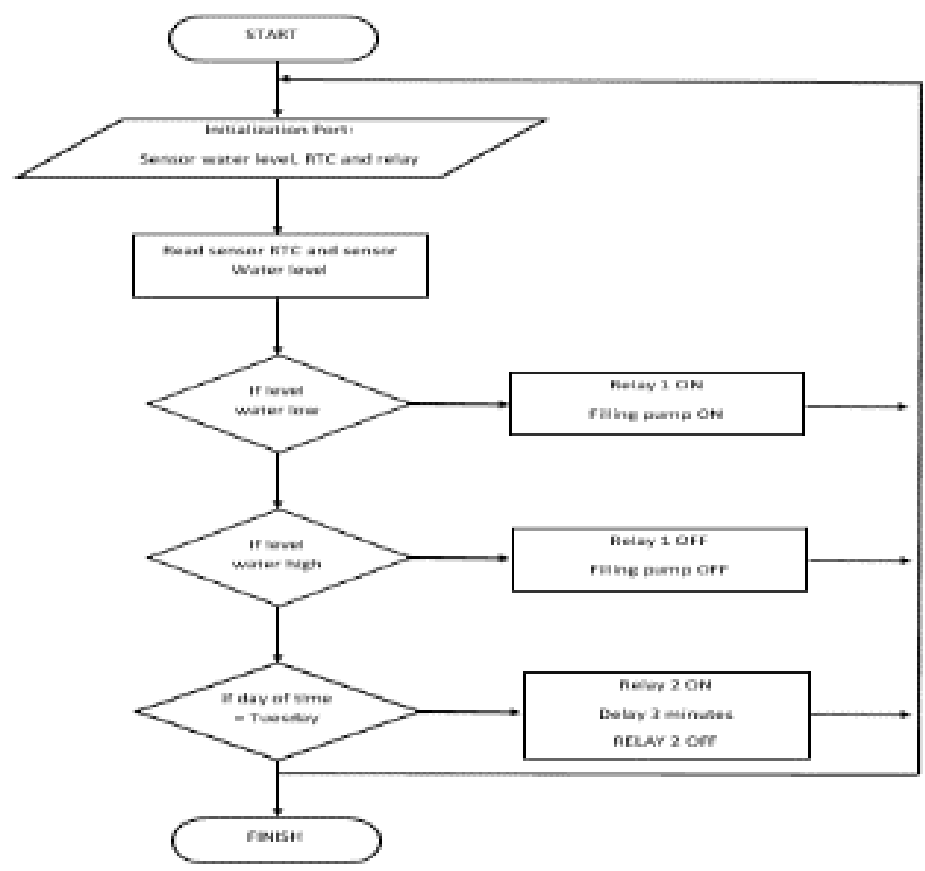

Figure 7. Flowchart System.

The following is the explanation of the flowchart design.

1. The first step is to initialize the variables used, such as the RTC sensor, water level sensor, and relay.

2. The sensor is on and ready to detect water levels and detect real-time.

3. Carry out orders following the conditions instructed.

a. First condition: If the water level $=$ LOW or lack of water then Arduino will turn on relay 1 and the filling pump will start to fill the water.

b. Second condition: If the water level $=\mathrm{HIGH}$ or the water level is at a high volume then Arduino will turn off relay 1 and the filling pump will OFF. 
c. Third condition: If the day of time or day = Tuesday then relay 2 is $\mathrm{ON}$, the fertilization pump is ON then a delay of 3 minutes, relay 2 OFF the fertilizer pump is OFF.

4. Instructions are always repeated (looping).

5. Done

\section{Conclusions}

This research has succeeded in designing an automation system prototype for hydroponic vegetable cultivation. This automation system prototype can be applied to various types of hydroponic vegetables.

\section{Acknowledgments}

The author would like to thank the Lampung State Polytechnic, especially the Research and Community Service Unit (UPPM) which has provided funding through the DIPA 2020 Research and Community Service grant.

\section{References}

[1] Badan Pusat Statistik. BPS 2018 Proyeksi Penduduk Indonesia 2015-2045 Hasil SUPAS 2015. Katalog 2101015. Kementan PPN/Bappenas. Jakarta.

[2] Eridani, D 2017 Designing and Implementing the Arduino-based Nutrition Feeding Automation System of a Prototype Scaled Nutrient Film Technique (NFT) Hydroponics using Total Dissolved Solids (TDS) Sensor. In The 2017 4th International Conference on Information Technology, Computer and Electrical Engineering (ICITACEE).

[3] Kustanti, I., Muslim, M. A., and Yudaningtyas, E 2014 Pengendalian Kadar Keasaman (pH) Pada Sistem Hidroponik Stroberi Menggunakan Kontroler PID Berbasis Arduino Uno. Jurnal Ika Kustanti, Surabaya.

[4] Helmy, H., Nursyahid, A., and Setyawan, T. A., \& Hasan, A 2016 Nutrient Film Technique (NFT) Hydroponic Monitoring System. JAICT, 1(1).

[5] Wahyudin, Y., and Suryono, S. E 2017 Sistem monitoring dan otomasi pengontrolan kelembaban media tanam (soil moisture) pada tanaman hidroponik berbasis web. Youngster Physics Journal Vol. 6, No. 3, Juli 2017, Hal. 213-220. ISSN: 2302 - 7371

[6] Yudhana, A., and Putra, M.C.F 2016 Penyiram Tanaman Otomatis Berbasis Informasi Sinyal Sensor Kelembaban, Prosiding Annual Research Seminar, Vol 2 No. 1 Universitas Sriwijaya, 2016.

[7] Pratama, I.G.B., Rasmana, S.T., and Puspasari, I 2016 Kontrol Kondisi Air Secara Otomatis Pada Tanaman Hidroponik. Journal of Control and Network System Vol.5 No.2

[8] Ibadarrohman., Salahuddin, N.S., and Kowand, A 2018 Sistem Kontrol dan Monitoring Hidroponik berbasis Android. Konferensi Nasional Sistem Informasi 2018. STMIK ATMA LUHUR Pangkalpinang, 8 -9 Maret 2018.

[9] Julyana, S.M., Suhendar, R.M., and Janizal 2017 Sistem Pengendalian Nutrisi Pada Tanaman Kangkung Hidroponik Menggunakan Mikrokontroler Arduino Mega 2560. ELEKTRA, Vol.3, No.2, Juli 2018, Hal. 69 - 72 ISSN: 2503-0221. Pp 69-72. 